DOI https://doi.org/10.30525/978-9934-26-007-0-12

\title{
П'ЯТЬ ПІДХОДІВ ДО ВИБОРУ ПРАВА АРБІТРАЖНОЇ УГОДИ В МІЖНАРОДНІЙ АРБІТРАЖНІЙ ПРАКТИЦІ
}

\author{
Кабрера Ю. Ф.
}

Science is organized common sense where many a beautiful theory was killed by an ugly fact. Thomas Huxley

\section{ВСТУП}

Міжнародний комерційний арбітраж кардинально відрізняється від національного правосуддя, адже в його основі закладена ідея іноземного елементу, а отже, ми завжди матимемо справу з більш ніж однією системою права. Їх можна ідентифікувати щонайменше п'ять:

1) закон, застосовуваний до суті спору, - матеріальне право;

2) закон, що регулює процедуру арбітражного трибуналу, - процесуальне право;

3) закон, що регулює арбітражну угоду та виконання цієї угоди;

4) закон, що регулює визнання та виконання арбітражного рішення (який на практиці може виявитися не одним законом, а двома і більше, якщо потрібно визнання та виконання в більш ніж одній юрисдикції, в якій сторона, котра програла арбітраж, має свої активи);

5) вказівки та рекомендації.

Всі ці системи права існують у взаємодії. По суті, вони являють собою один злагоджений механізм, який складається з багатьох різних деталей. Кожен елемент такої структури має неодмінний вплив на роботу всієї системи. Один із таких - це закон арбітражної угоди (арбітражного застереження). Тому метою цієї статті є дослідження та аналіз підходів вибору права, що застосовується до арбітражної угоди, які існують у світовій арбітражній практиці, та порівняння їх з українськими правовими реаліями.

Методологічною основою роботи стали загальнонаукові та спеціальні методи наукового пізнання, такі як метод аналізу та узагальнення судової практики, синтезу, формально-логічний метод, метод узагальнення та прогнозування, діалектичний та порівняльно-правовий методи. 


\section{1. Підходи вибору права арбітражної угоди, розроблені світовою арбітражною практикою}

Право, що застосовується до арбітражного застереження, регулює укладання, чинність, примусове виконання, припинення арбітражної угоди та підпорядковує такі аспекти: формальні вимоги до арбітражної угоди, арбітрабельність іiї предмета, іiі автономність щодо договору, в якому угода міститься, здатність арбітрів приймати рішення про власну юрисдикцію та ступінь, в якому судовий перегляд допустимий ${ }^{1}$. Здебільшого сторони не обирають право до арбітражної угоди, за таких обставин його здійснює арбітр. Існують різні підходи для визначення такого закону арбітром, що розвинулися у світовій арбітражній практиці.

Перший метод - традиційний. Він покладається на колізійні норми для визначення застосовного права до матеріальної чинності арбітражної угоди. Ці норми містять різні сполучні фактори в кожній країні - lex causae, locus regist actum, lex fori, автономія волі та ін., що дозволяють арбітражному застереженню підпорядковуватися іншому закону ніж тому, що регулює основний договір. Цей метод детермінації закону до арбітражної угоди $є$ найстарішим і найпоширенішим ${ }^{2}$.

Здебільшого арбітражні трибунали посилаються на п. 1 (a) ст. 5 НьюЙоркської Конвенції (далі - Конвенція 1958 р.), розглядаючи місце арбітражу як відповідний фактор для визначення застосовного закону, якщо жоден закон не був обраний сторонами ${ }^{3}$ : у визнанні і виконанні арбітражного рішення може бути відмовлено на прохання тієї сторони, проти якої воно спрямоване, тільки якщо ця сторона подасть до компетентної влади за місцем, де порушене клопотання про визнання і приведення у виконання докази того, що п. 1 (a) ст. 5: «сторони угоди, зазначеній у ст. 2 (тобто, арбітражного застереження) відповідно до застосовуваного до них закону були якоюсь мірою недієздатні або така угода (арбітражне застереження) $є$ недійсною за законом, якому сторони іiі підпорядкували, а за відсутності такої вказівки (вказівки на застосовуваний закон до арбітражного застереження), за законом країни винесення арбітражного рішення ${ }^{4}$. У ст. 34 (оспорювання арбітражного рішення) (2) (а) (i) та ст. 36 (відмова у визнанні та виконанні арбітражного рішення) (1) (a) (i) Типового закону ЮНСІТРАЛ ${ }^{5}$ відтворені аналогічні положення.

\footnotetext{
${ }^{1}$ United Nations conference on Trade and Development Dispute Settlement. URL: https://unctad.org/en/ Docs/edmmisc232add39_en.pdf. (дата звернення: 27.10.2020).

${ }^{2}$ Bonomi A., Volken P. Yearbook of Private International Law / ed. A. Bonomi, P. Volken. Lausanne : Swiss Institute Comparative Law, 2009. P. 104.

${ }^{3}$ Lew J. D. M., Mistelis L. A., Kröll S. M., Kröll S. Comparative International Commercial Arbitration. Alphen aan den Rijn : Kluwer Law International B.V., 2003. P. 124.

${ }^{4}$ Redfern A., Hunter M. On International Arbitration. Oxford : Oxford University Press, 2015. P. 159.

${ }^{5}$ Типовой закон ЮНСИТРАЛ о международном торговом арбитраже. URL: https://zakon.rada.gov.ua/laws /show/995_879. (дата звернення: 27.10.2020).
} 
Конвенція 1958 р. не містить інформації про те, як визначити, де рішення було винесено. Суди, як правило, визначають місце проведення арбітражного засідання як місце винесення арбітражного рішення ${ }^{6}$. Тобто, якщо місце проведення арбітражного засідання у Франції, значить, Франція буде місцем винесення арбітражного рішення, а отже, це означає, що арбітражна угода підпорядковується французькому закону. Хоча у справі Outhwaite v. Hiscox, арбітражний трибунал дійшов такого висновку: «Якщо в рішенні зазначено, що воно датується або підписується в певному місці, це і буде місцем, де воно було винесене. Якщо таких даних у рішенні нема, то воно має бути винесене в тому місці, де воно надається сторонам або з якого відсилається сторонам ${ }^{7}$. Проте, щоб уникнути таких непорозумінь, вже можна зустріти сучасні регламенти, в яких чітко визначено місце арбітражу ${ }^{8}$, навіть якщо засідання буде проводитися деінде.

Застосування закону країни місця винесення арбітражного рішення не обмежується посиланням на Конвенцію 1958 р., але ще й є можливим завдяки методу «найбільш тісного зв'язку» the closest connection test арбітражної угоди 3 місцем проведення арбітражного засідання. Гарним прикладом є справа № А3\2012\0249 Sulamerica Cia Nacional de Seguros SA v. Enesa Engenharia SA $2012^{9}$. Сторони уклали два поліси страхування ризику, пов'язані з будівництвом гідроелектростанції в Бразилії. Ці поліси містили чіткі положення, що договір регулюється бразильським законодавством, та виключне положення про юрисдикцію на користь бразильських судів. Арбітражне застереження передбачало арбітраж у Лондоні відповідно до Aida Reinsurance and Insurance Arbitration Society (ARIAS) Arbitration Rules, але не містило положення про закон, застосовний до арбітражної угоди.

Суть справи полягала у тому, що сторони зробили мовчазний вибір права Бразилії як застосовуваного закону до арбітражної угоди. На підтвердження цього вони покладалися на три основні фактори: 1) явний вибір права Бразилії для регулювання полісу в поєднанні з угодою про те, що суди Бразилії повинні мати виключну юрисдикцію стосовно будь-яких спорів, що виникають через або у зв'язку з полісом; 2) тісний комерційний зв'язок між полісом та державою Бразилія (сторони, предмет страхування та валюта полісу, і португальська мова, якою всі документи написані);

\footnotetext{
${ }^{6}$ UNCITRAL Secretariat Guide on the Convention on the Recognition and Enforcement of Foreign Arbitral Awards (New York, 1958). URL: https://www.uncitral.org/pdf/english/texts/arbitration/NY-conv/2016_Guide_on_ the_Convention.pdf. (дата звернення: 27.10.2020).

${ }^{7}$ Arbitration Award. URL: http://www.uniset.ca/lloydata/css/19921AC562.html. (дата звернення: 27.10.2020).

${ }^{8}$ Rules of COIA. URL: http://coia.org/wp-content/uploads/2015/10/151001-COIA-Arbitration-Rules.pdf. (дата звернення: 27.10.2020).

${ }^{9}$ Arbitration Award. URL: http://newyorkconvention1958.org/index.php?lvl=notice_display\&id=886\&opac_ view=6. (дата звернення: 27.10.2020).
} 
3) включення положення про медіацію, яке, як зазначалося, також регулювалося бразильським правом. 3 вищепереліченого найбільший акцент робився сторонами на тому, що вони вибрали право Бразилії як матеріальне право полісу. Страхувальник заявив, що відповідно до бразильського законодавства арбітражна угода проти них не є дійсною, якщо не має згоди з їхньої сторони.

Трибунал вказав таке: «Вже давно визнано, що належне право арбітражної угоди, яка сама формує частину основного договору, може відрізнятися від закону договору, але, мабуть, справедливо почати 3 припущення, що за відсутності будь-якої вказівки на протилежне, сторони мали намір підпорядкувати всі свої відносини тій самій системі права. Сторони зазвичай роблять явний вибір права для регулювання їхнього контракту, але для них вкрай незвично робити явний вибір регулюючого права для арбітражного застереження, що міститься в ньому, і якщо вони цього не зробили, то природним висновком $є$ те, що сторони мали намір застосувати явно обране ними матеріальне право контракту також для регулювання арбітражного застереження». Суду було важливо дати відповідь на запитання, чи сторони мовчазно обрали закон Бразилії для арбітражної угоди. Якщо ні, то з якою системою права арбітражна угода має найтісніший зв'язок? Арбітр дійшов висновку: «Я не вважаю, що явний вибір права Бразилії сторонами до основного договору є достатнім доказом мовчазного (ймовірного) вибору бразильського закону до арбітражної угоди, адже є ризик, що застосування бразильського законодавства істотно підірве правосильність арбітражної угоди. Також я не думаю, що сторони могли обрати будь-яку іншу систему права, яка призвела б чи могла б призвести до такого самого ефекту. Це, як мені здається, відображає той факт, що хоча і можна почати 3 припущення, що сторони мали на увазі один i той самий закон для всього контракту, включаючи арбітражне застереження, проте конкретні фактори можуть призвести до висновку, що насправді це не було їхнім наміром. Зрештою, я не можу визнати, що сторони зробили мовчазний вибір бразильського законодавства до арбітражної угоди».

Арбітражний трибунал вказав, що належним законом арбітражної угоди в цій справі було англійське законодавство, незважаючи на вибір бразильського права. Він вважав, що ключовим моментом була вага, яку потрібно надати вибору Лондона як місця арбітражу. Вибір місця арбітражу визначає процесуальне право та контроль юрисдикції судів країни, де місце арбітражу розташоване, у цьому випадку - Англії. Це призвело до чіткого висновку, що закон, з яким угода про арбітраж має найтісніший і найбільш реальний зав'язок, - це закон Англії. 
Своєю чергою англійський апеляційний суд постановив, що закон арбітражної угоди має бути визначений шляхом застосування триетапного розслідування:

1) прямий вибір сторін;

2) неявний (мовчазний) вибір закону сторонами;

3) там, де неможливо було встановити закон арбітражної угоди шляхом імплікації (тлумачення неявного вибору), варто було б розглянути, яким був би закон із «найбільш тісним і реальним зв'язком» 3 арбітражною угодою.

У принципі, ці етапи мали бути виконані окремо і саме в такому порядку, оскільки будь-який вибір, зроблений сторонами, має дотримуватися. Проте неодноразово зазначалося, що на практиці етап 2 переходить в етап 3, оскільки ідентифікація системи права, 3 якою угода має найтісніший i реальний зв'язок, може бути важливим фактором у вирішенні питання, чи сторони зробили ймовірний вибір права ${ }^{10}$.

Обгрунтуванням застосування закону місця арбітражу у цвй справі був найбільш тісний зв'язок або тест центру ваги, який сам по собі $\epsilon$ загальновизнаним принципом колізійних норм ${ }^{11}$.

Отже, системою англійського права був вироблений механізм під назвою «Sulamerica approach», що складається з триступеневого підходу в якому, поперше, сторони явно вказують на застосовний закон до арбітражної угоди. По-друге, за відсутності чіткого вибору такого закону арбітр аналізує мовчазний вибір сторін, i, якщо сторонами було обране застосовуване право контракту (матеріальне право), то арбітр буде застосовувати таке матеріальне право контракту також i до арбітражного застереження. Проте, якщо ефект такого матеріального права може істотно підірвати правосильність арбітражної угоди, то арбітр, керуючись ідеєю, що сторони не можуть обрати закон, котрий робить недійсним арбітражне застереження, застосовуватиме інший колізійний метод - «тісного зв'язку» угоди 3 певною системою права. У цьому випадку «найбільш тісний зв'язок» 3 контрактом мав закон місця проведення арбітражного засідання - це було англійське право.

На додачу, варто вказати ще на одну справу Enka Insaat Ve Sanayi AS v OOO Insurance Company Chubb 2020 року, що розглядалася Верховним Судом Великобританії (UKSC). Спір виник із того, що субпідрядник Enka, який брав участь у будівництві Березовської вугільної електростанції в Росії,

\footnotetext{
${ }^{10}$ Arbitration Award. URL: http://www.bailii.org/cgi-bin/format.cgi?doc=/ew/cases/EWCA/Civ/2012/638. html\&query $=(\mathrm{A} 3 / 2012 / 0249) \quad$ тa https://www.trans-lex.org/311350/_/sulamerica-cia-nacional-de-seguros-sa-venesa-engenharia-sa-\%5B2012\%5D-ewca-civ-638/. (дата звернення: 27.10.2020).

${ }^{11}$ Berger K.P. Re-Examining the Arbitration Agreement, Applicable Law Consensus or Confusion? URL: https://www.trans-lex.org/100680/_/berger-klaus-peter:-re-examining-the-arbitration-agreement-applicablelaw-consensus-or-confusion-in:-van-den-berg-icca-congress-ser-no13-international-arbitration-2006:-back-tobasics-/\#Footnote-817476356603a56a2029b62796fe7833. (дата звернення: 27.10.2020).
} 
$\epsilon$ частково відповідальним за масштабну пожежу, яка пошкодила завод у 2016 р. через неякісні роботи. Договір між Enka та головним підрядником містив арбітражне застереження, що передбачало арбітраж у Лондоні. Водночас контракт прямо не визначав регулююче право ні для договору, ні до арбітражної угоди. Тому виникло запитання, яким чином треба обирати право до арбітражної угоди.

Суд узагальнив принципи, що регулюють визначення законодавства до арбітражної угоди в таких випадках:

1. Якщо контракт містить угоду про врегулювання суперечок, що виникають із нього шляхом арбітражу, законодавство, що застосовується до арбітражної угоди, може бути не таким, як право, що застосовується до інших частин договору і має бути визначене із застосуванням англійських норм загального права для вирішення колізій законів, а не положеннями Регламенту Рим I.

2. Згідно з цими нормами, закон, застосовуваний до арбітражної угоди, буде:

a) закон, вибраний сторонами до арбітражної угоди.

б) за відсутністю такого вибору сторін, система права, з якою арбітражна угода має «найбільш тісний зв'язок».

3. Чи домовилися сторони про вибір закону до арбітражної угоди, 3'ясовується шляхом тлумачення арбітражного застереження та договору, що його містить, загалом застосовуючи норми договірного тлумачення англійського права як права країни місця судового засідання.

4. Там, де законодавство, застосовуване до арбітражної угоди, не вказане, вибір регулюючого права контракту, як правило, застосовується до арбітражної угоди, яка $є$ частиною контракту.

5. Вибір іншої країни як місця арбітражу не є, без іншого, достатнім, щоб спростувати умовивід про те, що вибір закону регулюючий контракт був призначений для застосування до арбітражної угоди.

6. Додатковими факторами, які можуть заперечувати такий висновок i у деяких випадках означають, що арбітражна угода мала на меті регулюватися законом місця арбітражу, $є$ такі:

a) будь-яке положення закону країни місця арбітражного суду, яке визначає, що якщо арбітраж підпорядковується цьому закону (країни місця арбітражного суду), арбітраж буде розглядатися як такий, що регулюється законодавством цієї країни;

б) наявність серйозного ризику того, що в разі підпорядкування арбітражної угоди тому самому праву, яким регулюється матричний контракт, призведе до неефективності такої угоди. Кожен із факторів може бути посилений обставинами, які свідчать про те, що місце арбітражу було навмисно вибране як нейтральне місце проведення арбітражного засідання. 
7. За відсутності чіткого вибору закону, що регулює договір, застереження, яке передбачає арбітраж у певному місці, саме по собі не обгрунтовує висновку про те, що контракт (або арбітражна угода) має регулюватися законодавством цього місця.

8. За відсутності будь-якого вибору закону для регулювання арбітражної угоди остання буде регулюватися законом, з яким вона найбільш тісно пов'язана. Коли сторони обрали місце проведення арбітражу, це, як правило, буде закон місця проведення арбітражного засідання, навіть якщо такий закон відрізнятиметься від права, застосовуваного до основних договірних зобов'язань сторін (тобто матеріальне право контракту).

9. Той факт, що контракт вимагатиме від сторін спроби вирішення спору методом добросовісних переговорів, посередництва або будь-якої іншої процедури перед передачею його в арбітраж, як правило, не буде підставою для витіснення закону місця арбітражу, як права, що застосовується до арбітражної угоди за замовчуванням за відсутності вибору закону для ії регулювання.

I тому, застосовуючи ці принципи, суд дійшов висновку, що договір, 3 якого виник спір, не містить пункту вибору права, який би мав на меті регулювати контракт і арбітражне застереження в ньому. За таких обставин, дійсність та обсяг арбітражної угоди (i, на думку суду, увесь спір) регулюється законом вибраного місця проведення арбітражного засідання як право, з яким положення про вирішення спорів має найбільш тісний зв'язок. Тому суд підтвердив, що закон, застосовуваний до арбітражного застереження, - це англійське право ${ }^{12}$.

Отже, остання практика англійських судів демонструє, що у разі відсутності закону, вибраного сторонами до арбітражної угоди, арбітражні трибунали застосовуватимуть підхід the closest connection test. Тест обрання закону до арбітражної угоди, з яким вона має «найбільш тісний і реальний зв'язок», означає: а) в першу чергу застосування права, вибраного сторонами до їхнього контракту для регулювання арбітражного застереження. Якщо матеріальне право контракту буде, наприклад, китайське право, то арбітражна угода буде регулюватися китайським правом. Проте в ситуації, коли матеріальне право договору, вибране сторонами, буде істотно підривати чинність арбітражного застереження, або ж сторони не вибрали матеріальне право, що регулює їхній договір, арбітражний суд в Англії буде застосовувати закон країни місця проведення арбітражного засідання.

\footnotetext{
${ }^{12}$ Arbitration Award. URL: https://www.supremecourt.uk/cases/docs/uksc-2020-0091-judgment.pdf, P. 59-60. (дата звернення: 27.10.2020).
} 
Другий метод - «validation principle», або принцип надання юридичної сили. Деякі правові системи, намагаючись підтримати ідею чинності арбітражної угоди, розробили ще один колізійний метод, який має альтернативну тривимірну форму. Це п. 2 ст 178 Швейцарського закону про міжнародне приватне право SPILA: «Стосовно матеріальної чинності, арбітражна угода $є$ дійсною, якщо вона відповідає закону, вибраному сторонами, закону, що регулює предмет спору, зокрема, основного договору, або закону Швейцарії». Отже, стосовно матеріальної чинності арбітражної угоди п. 2 ст. 178 SPILA встановлює колізійну норму in favorem validatis, відповідно до якої дійсність арбітражної угоди буде підтримуватися настільки, наскільки вона відповідатиме вимогам матеріальних норм викладеним у будь-якому 3 трьох перелічених законів, вказаних у п. 2 ст. 178. Мета цього положення - забезпечити, наскільки це можливо, дійсність арбітражної угоди, хоча ця стаття не конкретизує, які саме питання підпадають під поняття «матеріальної чинності» арбітражної угоди. Область застосування зазвичай включає укладання арбітражної угоди (пропозиція, акцепт, згода у випадках, коли арбітражні застереження включені шляхом посилання, недоліки наміру та можливі недоліки згоди, такі як помилка, примус, введення в оману), можливі передумови арбітражу (наприклад, попередня медіація), проблеми виконання (затримка, неможливість, exceptio non adimpleti contractus - заперечення про невиконання контрагентом договірних зобов'язань) та сферу застосування арбітражної угоди (наприклад, зобов'язальна сила щодо непідписантів або правонаступників). Усі аспекти чинності угоди мають бути вивчені відповідно до одного закону, а не застосовувати будь-який із трьох можливих законів вибірково до окремих питань. Дискусійним $є$ те, чи можуть застосовуватися відповідно до п. 2 ст. 178 лише національні правові системи чи також ненаціональні норми права, наприклад, lex mercatoria ${ }^{13}$.

Такий самий підхід має у своїй основі Арбітражний Акт Іспанії. П. 6 ст. 9 вказує: «У міжнародному арбітражі, арбітражна угода буде дійсною, а спір арбітрабельним, якщо хоча б одна 3 вказаних вимог буде дотриманою: правові норми, вибрані сторонами для регулювання арбітражної угоди; правила, що застосовуються до суті спору; або норми, встановлені іспанським законодавством» ${ }^{14}$.

\footnotetext{
13 Swiss Private International Law Act (Chapter 12: international arbitration): A Comentary. URL: https://www.swlegal.ch/media/filer_public/9d/b2/9db20052-18a2-4b68-a131-e70ff5bb7ec3/150921_anya-george_ swiss-private-international-law-act-chapter-12-international-arbitration.pdf. (дата звернення: 27.10.2020).

${ }^{14}$ Act 60/2003 on Arbitration. URL: https://www.mjusticia.gob.es/cs/Satellite/Portal/1292426982249? blobheader=application $\% 2 F p d f \&$ blobheadername $1=$ Content-Disposition \&blobheadervalue $1=$ attachment $\% 3 \mathrm{~B}+$ filename\%3DAct_on_arbitration_\%28Ley_60_2003_de_arbitraje\%29.PDF. (дата звернення: 27.10.2020).
} 
Можна побачити, що існує певна альтернативна структура. Якщо, за одним законом, арбітражне застереження є недійсним, то чинність угоди на арбітраж можна підтримати іншим законом. Такий принцип має назву «validation principle» - принцип чинності/дійсності угоди на арбітраж.

Ст. 4 Резолюції, прийнятої Інститутом Міжнародного Права сесії Сантьяго де Компостела 1989 р. про арбітраж між державами, державними підприємствами чи державними суб'єктами та іноземними підприємствами, пропонує навіть ширший підхід для підтримання чинності арбітражної угоди: «Якщо оскаржується дійсність угоди про арбітраж, трибунал вирішує це питання, застосовуючи одне чи більше 3 наступного: закон вибраний сторонами; закон зазначений у системі міжнародного приватного права, передбаченій сторонами; загальні принципи міжнародного публічного чи приватного права; загальні принципи міжнародного арбітражу або закону країни місця проведення арбітражу. Здійснюючи цей вибір, трибунал керується у кожному випадку принципом in favorem validatis» ${ }^{15}$.

Отже, виявляється певна тенденція в міжнародній арбітражній практиці- осмислювати початкове джерело своїх повноважень із точки зору відносної автономії від муніципального законодавства. Інститут Міжнародного Права надав свій науковий відтиск схвалення такій концепції порівняної незалежності автономії у вищевказаному документі. Резолюція проголошує перевагу автономії волі та визнає так званий принцип in favorem validatis як головне правило чинності. Та, зокрема, стверджує, що чинність арбітражного застереження може випливати з обох, як із муніципальних, так і 3 міжнародних правових стандартів, дозволяючи недійсність лише в порядку порушення міжнародного публічного порядку. Резолюція мала на меті наголосити, що повноваження арбітражного процесу як системи вирішення спорів, не походять від дискретного суверена, а швидше від міжнародного порядку ${ }^{16}$. Варто уточнити, що ця резолюція підтримує такий підхід у контексті державних контрактів.

Третій метод - закон основного договору регулюс арбітражне застереження. Правом арбітражної угоди не $\epsilon$ обов'язково закон, що регулює основний договір, навіть якщо арбітражне застереження включене в договір,

\footnotetext{
${ }^{15}$ Session of Santiago de Compostela - 1989 Arbitration Between States, State Enterprises, or State Entities, and Foreign Enterprises. URL: https://www.idi-iil.org/app/uploads/2017/06/1989_comp_01_en.pdf. (дата звернення: 27.10.2020).

${ }^{16}$ Alvik I. Contracting with Sovereignty: State Contracts and International Arbitration. London: Bloomsbury Publishing, 2011. P. 111-114.
} 
хоча на практиці закон основного договору буде, ймовірно, регулювати арбітражну угоду ${ }^{17}$.

Існує сильна тенденція на користь застосування матеріального закону, що регулює основний контракт до арбітражного застереження. У справі Sonatrach Petroleum Corporation (BVI) v Ferrell International Limited суддя вказав: «Якщо основний договір містить явний вибір закону, але арбітражна угода не має окремого прямого вибору права, то до неї, як правило, буде застосовуватися звід правових норм, явно обраних регулювати основний контракт» 18 .

Такий самий підхід підтверджено сингапурським судом у справі $\boldsymbol{B C}$ $\boldsymbol{v} \boldsymbol{B C Z} 2016$, де арбітр постановив, що законом арбітражного застереження буде закон Нью-Йорка. Якщо сторони не вибрали явний закон для арбітражної угоди, існувала спростовувана презумпція, що вони мовчазно обрали той закон, який регулює основний договір. Оскільки регулюючим правом основного договору був закон Нью-Йорку, законом до арбітражної угоди буде той самий закон. Не було жодних факторів, що витісняли б цю спростовувану презумпцію. У цій справівартим уваги для подальшого дослідження $\epsilon$ також те, що, арбітр, застосовуючи закон Нью-Йорку щодо утворення контракту, встановив, що арбітражна угода вважалася укладеною тоді, коли позивач заявив про готовність до підписання проекту і відхилив заяву відповідача, що угода існувала після обміну другого проєкту, адже на той час не існувало об'єктивного прояву взаємної згоди бути пов'язаними арбітражною угодою. Своєю чергою про взаємну згоду можна було б зробити висновок з обмінів наступними проєктами, які мали однакове арбітражне застереження ${ }^{19}$.

Подібним чином в іншій справі Sumitomo Heavy Industries Ltd v Oil \& Natural Gas Commission 1997, в якій арбітр зазначив, що вибір матеріального закону, який регулює контракт, як правило, буде головним у процесв визначення закону для арбітражної угоди ${ }^{20}$. У справі Leibiner v Stryker Trauma GmbH 2005 належним правом угоди на арбітраж у Лондоні

\footnotetext{
${ }^{17}$ Graffi L. The law applicable to the validity of an arbitration agreement: a practitioner's view URL: https://books.google.co.il/books?id=Zx4eFIqD0wsC\&pg=PA51\&lpg=PA51\&dq=lew+there+is+a+very+strong+ presumption+in+favour+of+the+law+governing+the+substantive+agreement+which+contains+the+arbitration+ clause+also+governing+the+arbitration+agreement\&source=bl\&ots=E9RRp9YB4q\&sig=ACfU3U3FB5sku4OFrSj2 vi2OrEECGIB8Pw\&hl=ru\&sa=X\&ved=2ahUKEwje9dvd0tPoAhXLDOwKHY8vA3oQ6AEwAXoECAsQNQ\#v= onepage\&q=lew\%20there $\% 20$ is $\% 20 \mathrm{a} \% 20$ very $\% 20$ strong\%20presumption $\% 20 \mathrm{in} \% 20$ favour\%20of $\% 20$ the $\% 201$ aw $\% 20$ governing $\% 20$ the $\% 20$ substantive $\% 20$ agreement $\% 20$ which $\% 20$ contains $\% 20$ the $\% 20$ arbitration $\% 20$ clause $\%$ 20also\%20governing\%20the\%20arbitration\%20agreement\&f=false. (дата звернення: 27.10.2020).

${ }^{18}$ Arbitration Award. URL: http://www.bailii.org/ew/cases/EWHC/Comm/2001/481.html, 32. (дата звернення: 27.10.2020).

${ }^{19}$ Arbitration Award. URL: https://www.supremecourt.gov.sg/docs/default-source/module-document/judgement/ bcy-v-bcz-(for-release)-(08-11-2016)-pdf.pdf, 32. (дата звернення: 27.10.2020).

${ }^{20}$ Arbitration Award. URL: https://indiankanoon.org/doc/216597/. (дата звернення: 27.10.2020).
} 
було німецьке законодавство через те, що сторони явно обрали німецьке право як регулюючий закон контракту, до якого арбітражна угода (хоч i містилася в окремому документі) була доповненням ${ }^{21}$.

Четвертий - прямий метод. Окрім всіх вищезгаданих методів і технік, французька система розвинула альтернативний метод, який складається 3 матеріальних положень міжнародного приватного права, що застосовуються до міжнародних відносин. Він має назву прямий метод ${ }^{22}$. У справі Municipalite de Khoms El Mergeb v. Societe Dalico 1993 року № 91-16828 суд вказа: «Згідно з матеріальним правилом міжнародного арбітражного права арбітражне застереження $є$ юридично незалежним від основного договору, в якому воно міститься або до якого належить. Існування та ефективність арбітражної угоди слід оцінювати відповідно до загальних намірів сторін та без обов'язкового посилання на національне законодавство, за умови, що не порушуються обов'язкові положення французького законодавства та міжнародного публічного порядку» ${ }^{23}$. Відповідно до французького законодавства арбітражна угода $є$ повністю автономною і може розглядатися без посилання на національну правову систему ${ }^{24}$.

Також 8 липня 2009 року Верховний Суд Франції у справі № 08-16025 Société d'etudes et represantations navales et industrielles SOERNI v Société Air Sea Broker limited (ASB) ухвалив рішення, яке підтверджує його позицію про те, що існування та дійсність арбітражної угоди варто визначати насамперед у світлі загального наміру сторін. Справа стосувалася угоди про перевезення, укладеної $S O E R N I$ та $A S B$, щодо перевезення $A S B$ моторного човна 3 Лібревіля до Пуента Нуару. Угода між сторонами не містила жодного арбітражного застереження. Однак сторони також уклали лист про звільнення від відповідальності, в якому вказували арбітражне застереження, що містилося в накладній. $A S B$ ініціював арбітражне провадження, яке виникло внаслідок затоплення моторного човна на підставі арбітражного застереження, що міститься в накладній. Зрештою, арбітражний суд ухвалив рішення на користь $A S B$ і зобов'язав SOERNI

${ }^{21}$ Arbitration Award. URL: https://www.casemine.com/judgement/uk/5a8ff73160d03e7f57ea96dd.(дата звернення: 27.10.2020).

${ }^{22}$ Rubino-Sammartano M. International Arbitration Law and Practice. Huntington NY: Juris Publishing, 2014. P. 89.

${ }^{23}$ Arbitration Award. URL: https://www.legifrance.gouv.fr/affichJuriJudi.do?oldAction=rechJuriJudi\& idTexte=JURITEXT000007030314\&fastReqId=1260648628\&fastPos=1. (дата звернення: 27.10.2020). Див. також англ. переклад https://books.google.co.il/books?id=pcvfDgAAQBAJ\&pg=PT205\&lpg=PT205\&dq=Municipalite+ de+Khoms+El+Mergeb+v.+Societe+Dalico\&source=bl\&ots=KSIM6YvT_f\&sig=ACfU3U2jc_1J0AvUKA8XzO APpCBYBhbSBg\&hl=ru\&sa=X\&ved=2ahUKEwjGotyBpaboAhUTnVwKHbf8D1cQ6AEwBXoECAgQAQ\#v= onepage \&q=Municipalite $\% 20 \mathrm{de} \% 20 \mathrm{Khoms} \% 20 \mathrm{El} \% 20 \mathrm{Mergeb} \% 20 \mathrm{v} . \% 20$ Societe $\% 20 \mathrm{Dalico} \& \mathrm{f}=$ false. (дата звернення: 27.10.2020).

${ }^{24}$ Webster T. H., Dr Buhler M. Handbook of ICC Arbitration: Commentary, Precedents, Materials. London: Sweet \& Maxwell, 2014. P. 106. 
виплатити збитки ASB. SOERNI подав апеляцію до Верховного суду Франції, стверджуючи, що він не бачив арбітражного застереження перед тим, як укладав угоду про перевезення i, що, згідно з законодавством Франції, арбітражна угода, включена шляхом посилання, не є обов'язковою, якщо сторона не знає про їі зміст під час укладання договору, який посилається на неї. SOERNI також стверджував, що його представляв працівник, котрий не мав повноважень. У своєму рішенні Верховний суд Франції підтвердив чинність арбітражної угоди, заявивши, що питання про те, чи є сторона дійсно пов'язаною арбітражною угодою, слід досліджувати з огляду на спільний намір сторін, вимоги добросовісності та переконання, що особа, котра підписала контракт, мала повноваження зобов'язати компанію. Верховний суд не обговорював закон, що регулює арбітражну угоду, а розглянув лише такі релевантні факти: а) лист про звільнення від відповідальності чітко вказував на арбітражну угоду; б) працівник був єдиним контактом від $A S B$ в процесі переговорів; в) SOERNI ніколи не інформував $A S B$ про те, що їх працівнику не вистачало повноважень зобов'язувати $S O E R N I^{25}$.

Відповідно до французького законодавства чинність положення, що стосується міжнародного арбітражу (на відміну від внутрішнього) може бути безпосередньо виведена 3 матеріального правила автономії волі, використовуваного в міжнародному арбітражі. Основне обгрунтування такого підходу полягає саме у підтримці дійсності арбітражних угод на тлі ймовірних обмежень у національному законодавстві, які б застосовувалися б у протилежному випадку ${ }^{26}$.

Тобто французькі суди не застосовують метод колізійного аналізу для визначення дійсності арбітражної угоди, а лише беруть до уваги всі докази існування наміру сторін. Верховний суд неодноразово приймав таку позицію. Наприклад, справа № 91-15.194 Societe Bomar Oil N.V. v. Entreprise tunisienne d'activites petrolieres (ETAP) $1993^{27}$ та справа № 88-13336 Societe anonyme Francaise Entrepose GTM pour les Travaux Petroliers Maritimes (ETPM) v. Societe anonyme Empresa Constructoria Financiera (ECOFISA) $1990^{28}$.

Окрім цього, французька правова система пішла далі. У справі № 1513.151 від 16 травня 2016 р. Касаційний суд Франції вказав таке:

\footnotetext{
${ }^{25}$ Arbitration Award. URL: https://www.legifrance.gouv.fr/affichJuriJudi.do?oldAction=rechJuriJudi\& idTexte=JURITEXT000020837816\&fastReqId=1282389989\&fastPos=1. (дата звернення: 27.10.2020).

${ }^{26}$ Alvik I. Contracting with Sovereignty: State Contracts and International Arbitration. London: Bloomsbury Publishing, 2011. P. 112.

${ }^{27}$ Arbitration Award. URL: https://www.legifrance.gouv.fr/affichJuriJudi.do?idTexte=JURITEXT000007031033. (дата звернення: 27.10.2020).

${ }^{28}$ Arbitration Award. URL: https://www.legifrance.gouv.fr/affichJuriJudi.do?idTexte=JURITEXT000007099879. (дата звернення: 27.10.2020).
} 
«Прийняття арбітражного застереження $є$ презюмованим. Лише докази того, що копії підроблені можуть визнавати застереження недійсним». Згідно з французьким правом, для дійсності арбітражної угоди не вимагається, щоб вона була укладена у письмовому вигляді, якщо вона стосується міжнародного арбітражу (на відміну від внутрішнього, де письмова форма угоди на арбітраж є обов'язковою). Якщо рішення суду підлягає судовому перегляду перед юрисдикцією Франції, то вони мають шукати лише волю сторін на подання позову в арбітраж ${ }^{29}$. Тому ми можемо виокремити існування п'ятого методу, який можна назвати «презумпція арбітражного застереження».

Отже, коли мова заходить про чинність, дійсність арбітражного застереження, французька арбітражна практика вже починається навіть не 3 пошуку обопільної згоди сторін на арбітраж, а 3 презумпції, що арбітражні угоди $є$ дійсними. Ця презумпція спростовується, якщо оскаржуюча сторона може успішно довести інше.

\section{2. Вибір права арбітражної угоди в Україні}

Тепер варто поставити запитання: який підхід використовується в Україні? Чи існує «український підхід» до вибору права арбітражної угоди? Бачення цієї ситуації описала Т. Сліпачук: «Українське законодавство прямо не передбачає методу визначення права до арбітражної угоди. Проте певні вказівки щодо цього питання містяться у Конвенції 1958 р. та Законі України «Про Міжнародний комерційний арбітраж» (далі - МКА).

П. 1 ст. 36 Закону України «Про МКА» вказує, що у визнанні та виконанні арбітражного рішення може бути відмовлено, незалежно від того, в якій державі воно було винесено, якщо арбітражна угода $є$ недійсною за законом, якому сторони ii підпорядкували, а в разі відсутності такої вказівки за законом держави, де рішення було винесено.

Таке саме положення міститься у п. 1 (b) ст. 5 Конвенції 1958 р. На додачу Конвенція 1958 р. передбачає, що у визнанні і виконанні арбітражного рішення може бути відмовлено, якщо сторони арбітражного застереження були, відповідно до застосовуваного до них закону, певною мірою недієздатними.

Оскільки положення міжнародних договорів України, які відрізняються від відповідних положень українських законів, мають перевагу над положеннями законів України, Верховний суд України у своїй Постанові № 12 посилався на формулювання, що міститься у Конвенції 1958 p.

\footnotetext{
${ }^{29}$ Arbitration Award. URL: https://www.legifrance.gouv.fr/affichJuriJudi.do?idTexte=JURITEXT000032600615. (дата звернення: 27.10.2020).
} 
Таким чином, у практиці українських судів дійсність арбітражного застереження має розглядатися відповідно до закону, вибраного сторонами, або, якщо вибір відсутній, відповідно до закону країни винесення арбітражного рішення.

Що ж стосується проблеми скасування арбітражних рішень, винесених МКАС при ТПП України, то п. 2 ст. 34 закону України про МКА вказує, що таке рішення може бути скасоване, якщо арбітражне застереження $\epsilon$ недійсним за законом, якому сторони цю угоди підпорядкували, а в разі відсутності такої вказівки - за законом України» ${ }^{30}$.

Отже, з огляду на те, що зазначила Т. Сліпачук, складається загальне уявлення, що в Україні, за відсутністю права, вибраного сторонами, арбітражні судді мають посилатися на норми Конвенції 1958 p. i використовувати для вибору закону до арбітражного застереження закон країни місця винесення арбітражного рішення, а отже, закони України. 3 одного боку, через те, що інакшого способу просто не вказано, а з іншого через те, що положення Конвенції 1958 р. мають переважати над нормами українського законодавства. Тому у нас виникає запитання, чи дійсно це так. Чи можна зробити висновок, що арбітражний суддя МКАС при ТПП України має обирати право до арбітражної угоди, лише керуючись законом місця винесення арбітражного рішення на підставі положення п. 1 (b) ст. 5 Конвенції 1958 р.? 3 усією повагою, ми не можемо погодитися 3 концепцією, що пропонує шановна пані Т. Сліпачук, адже, проаналізувавши ситуацію в Україні, ми дійшли інших висновків і ось чому.

По-перше, на нашу думку, аналогічні положення, що містяться у п. 1 (1) ст. 36 Закону України «Про МКА», повторюються не у п. 1 (b) ст. 5 Конвенції 1958 р., а у п. 1 (а) ст. 5 Конвенції 1958 р.

По-друге, ми не можемо погодитися з ідеєю, що арбітражне застереження в українській арбітражній практиці має розглядатися крізь призму чітко окреслених та явно обмежених кордонів Конвенції 1958 р. І ось чому:

1) Чи дійсно положення міжнародних договорів України, а отже, i Конвенція 1958 р., мають перевагу над положеннями законів України?

У ч. 2 ст. 19 Закону України «Про міжнародні договори України» вказується, що якщо міжнародним договором встановлені інші правила, ніж ті, що передбачені у відповідному акті законодавства України, то застосовуються правила міжнародного договору ${ }^{31}$. В той же час у ст. 9 Конституції України, яка має найвищу юридичну силу і пряму дію, зазначено, що чинні міжнародні договори, згода на обов'язковість яких

\footnotetext{
${ }^{30}$ Liebscher C., Alice A. Fremuth-Wolf. Arbitration Law and Practice in Central and Eastern Europe. Huntington: Juris Publishing, Inc., 2006. P. 98.

31 Про міжнародні договори України: Закон України від 29.06.2004 р. № 1906-IV. Дата оновлення: 02.01.2020 p. URL: https://zakon.rada.gov.ua/laws/show/1906-15\#Tеxt. (дата звернення: 27.10.2020).
} 
надана Верховною Радою України, є частиною національного законодавства України $^{32}$. Ця стаття не встановлює чіткого примата міжнародного права над правом внутрішнім. Вона просто декларує, що договір $є$ частиною національного законодавства ${ }^{33}$. Отже, якщо міжнародні договори $\epsilon$ частиною національного законодавства, то ієрархічно вони все одно вищі від інших актів законодавства України через положення ч. 2 ст. 19 Закону України про міжнародні договори.

Також варто додати окрему думку, висловлену суддею Конституційного Суду України О.М. Тупицьким: «У своїй практиці Конституційний Суд країни послідовно керується принципом «дружнього ставлення» до міжнародно-правових норм, здійснюючи інтерпретацію положень Конституції та законів України толерантно щодо відповідних норм міжнародного права. Іншими словами, на рівні конституційного права тексти міжнародних договорів та практика їх інтерпретації компетентними міжнародними органами виконують допоміжну функцію» ${ }^{34}$. I, на додачу, потрібно звернути увагу на Постанову Пленуму Верховного Суду України № 9, в якій вказується, що міжнародні договори застосовуються, якщо вони не суперечать Конституції України ${ }^{35}$.

3 іншого боку, ст. 18 Конституції України встановлює, що загальнополітична діяльність України спрямована на забезпечення ऑiі національних інтересів за загальновизнаними принципами i нормами

\footnotetext{
${ }^{32}$ Конституція України: офіційний текст. URL: https://zakon.rada.gov.ua/laws/show/254\%D0\%BA/ 96-\%D0\%B2\%D1\%80\#Text. (дата звернення: 27.10.2020).

${ }^{33}$ О.О. Мережко висловив думку на своїй фейсбук сторінці стосовно ст. 9 Конституції України. Більш детально Мережко вказав наступне: «Проблематичность этой статьи, во-первых, в том, что она не устанавливает четкого примата международного права над правом внутренним. Она просто заявляет, что договор является частью «национального законодательства». Во-вторых, сама формулировка «договор часть национального законодательства» неверна и юридически некорректна. Правильнее было бы написать «договор - часть правовой системы». Об этом собственно, писал еще Лукашук. В-третьих, формулировка ст. 9 не учитывает другие источники международного права помимо договоров. Поэтому правильно было бы включить в ее текст хотя бы понятие основные принципы международного права. В-четвертых, статья не различает виды договора (межгосударственные, межправительственные, и межведомственные). А различать их было бы правильно, поскольку каждый такой вид договора должен занимать свое место в иерархии источников. В-пятых, было бы правильно различать самоисполнимые и несамоисполнимые положения договора. В-шестых, следовало бы также установить практику (по примеру Нидерландов) согласно которой суды могут осуществлять своеобразный контроль не только за соответствием законов Конституции но также за соответствием законов международно-правовым обязательствам Украины. В-седьмых, коль скоро ми закрепили в тексте конституции нашу цель - стать членом ЕС, то было бы весьма логично закрепить в Конституции особый статус права ЕС и его приоритет по отношению к праву национальному. Вообще говоря, Конституцию хотелось бы видеть, если можно так выразиться, более международно-правовой. Например, с большим количеством отсылок к нормам международного права, как это имеет место в конституциях некоторых европейских государств».

${ }^{34}$ Окрема думка судді Конституційного суду України Тупицького О.M. від 21.03.2014 p. URL: https://zakon.rada.gov.ua/laws/show/nb02d710-14\#Text. (дата звернення: 27.10.2020).

${ }^{35}$ Про застосування Конституції України при здійсненні правосуддя : Постанова Пленуму Верховного Суду від 01.11.1996 р. № 9. URL: https://zakon.rada.gov.ua/laws/show/v0009700-96\#Tехt. (дата звернення: 27.10.2020).
} 
міжнародного права. Також у Декларації про державний суверенітет України визнається пріоритет загальновизнаних норм міжнародного права перед нормами внутрішньодержавного ${ }^{36}$.

Тому це означає, що Україна визнає пріоритет загальновизнаних норм міжнародного права. Але мова йде про загальновизнані норми міжнародного права, які, як зазначив В.А. Ватрас, $є$ основоположними імперативними нормами, що приймаються і визнаються міжнародною спільнотою держав, відхилення від яких є недопустимим ${ }^{37}$, а не про Конвенцію 1958 р.

Отже, Україна визнає пріоритет загальновизнаних норм міжнародного права перед нормами внутрішньодержавного. Своєю чергою Конвенція 1958 р. має пріоритет над іншими законами України, але до тієї міри, до якої вона (Конвенція 1958 р.), не суперечить нормам Конституції України.

2) Чи дійсно Конвенція 1958 р. містить вказівки на метод визначення закону до арбітражної угоди?

Конвенція 1958 р. не передбачила детального правового режиму щодо всіх аспектів міжнародного арбітражу (як, наприклад, згодом це зробив Типовий закон ЮНСІТРАЛ 1985 р.). Швидше, положення Конвенції 1958 р. були зосереджені на визнанні та виконанні арбітражних угод та арбітражних рішень без особливого регулювання проведення арбітражних процедур чи інших аспектів арбітражного процесу. Ключовою метою Конвенції 1958 р. була уніфікованість: ii розробники прагнули встановити єдиний набір міжнародно-правових стандартів щодо виконання арбітражних угод та арбітражних рішень. Зокрема, положення Конвенції 1958 р. встановлюють єдині міжнародні правила, які:

a) вимагають від національних судів визнавати та виконувати іноземні арбітражні рішення (ст.ст. 3,4$)$ за умови обмеженої кількості визначених винятків (ст. 5);

б) вимагають від національних судів визнавати чинність арбітражних угод за певних винятків (ст. 2);

в) вимагають від національних судів направити сторони в арбітраж, коли вони уклали чинну угоду на арбітраж, що підпадає під дію Конвенції 1958 р. (п. 3 ст. 2$)^{38}$.

Отже, ст. 5 Конвенції 1958 р. (як і сама Конвенція 1958 р.) присвячена питанню визнання i виконання арбітражних рішень, а не проблемі визначення права застосовуваного до арбітражного застереження і прямих

\footnotetext{
${ }^{36}$ Декларація про державний суверенітет України від 16.07 .1990 p. № 55-XII. URL: https://zakon.rada.gov.ua/laws/show/55-12\#Text. (дата звернення: 27.10.2020).

${ }^{37}$ Ватрас В.А. Загальновизнані принципи і норми міжнародного права як джерела публічного та приватного права. URL: http://www.univer.km.ua/statti/20.vatras_v.a._zahalnovyznani_pryntsypy_i_normy_ mizhnarodnoho_prava_yak_dzherel_publichnoho_ta_pryvatnoho_prava.pdf. (дата звернення: 27.10.2020).

${ }^{38}$ Gary B. Born International Arbitration: Law and Practice, The Netherlands: Walters Kluwer, 2012. P. 48-49.
} 
вказівок на це вона не містить, так само як і Типовий Закон ЮНСІТРАЛ чи закон України Про МКА (який майже 3 точністю повторює положення Типового Закону ЮНСІТРАЛ).

По-третє, як зазначено секретаріатом ЮНСІТРАЛ у Керівництві до Конвенції 1958 р. про визнання та виконання арбітражних рішень стосовно п. 1 (а) ст. 5, недійсність арбітражної угоди, в першу чергу, оцінюється відповідно до закону, вибраного сторонами. Тому арбітражні трибунали застосовують систему права, вибрану сторонами до основного договору (матеріальне право договору), також i як закон, застосовуваний до арбітражного застереження, або процесуальне право арбітражу як неявний (мовчазний) вибір закону сторін ${ }^{39}$. Тобто, відштовхуючись від Конвенції 1958 р., арбітри мають змогу або прямо посилатися на закон країни місця винесення арбітражного рішення, або ж відшукують мовчазний вибір сторін і можуть його тлумачити, використовуючи на вибір: 1) матеріальне право основного договору сторін як закон до арбітражної угоди; 2) процесуальне право арбітражу. (Тут також варто додати, що процесуальне право може відрізнятися від місця проведення арбітражного засідання чи місця винесення арбітражного рішення. Але, як правило, якщо арбітраж інституційний, то закон країни місця проведення арбітражного засідання чи місця винесення арбітражного рішення буде таким самим, як і процесуальне право).

Отже, навіть якщо арбітр у МКАС при ТПП України прагне обрати закон арбітражного застереження, використовуючи Конвенцію 1958 р., то йому не обов'язково застосовувати тільки і лише закон країни місця винесення арбітражного рішення. Він може також застосувати той самий вибраний сторонами матеріальний закон контракту і до арбітражної угоди.

По-четверте, стосовно Постанови № $12^{40}$, то вона дійсно посилається на Конвенцію 1958 р., але лише на неї і загалом, а не до визначення закону арбітражного застереження, адже Постанова № 12 як і Конвенція 1958 р. стосується визнання і виконання та скасування арбітражних рішень.

По-п'яте, якщо українською правовою системою не закріплено жодного способу визначення закону до арбітражної угоди, чи має арбітр слідувати методу lex fori, lex arbitri, використовуючи Конвенцію 1958 р.?

Конституційним принципом $є$ принцип верховенства права (ст. 8 Конституції України), громадяни здійснюють свої права за принципом:

\footnotetext{
${ }^{39}$ UNCITRAL: Secretariat Guide on the Convention on the Recognition and Enforcement of Foreign Arbitral Awards. URL: https://www.uncitral.org/pdf/english/texts/arbitration/NY-conv/2016_Guide_on_the_Convention. pdf. (дата звернення: 27.10.2020).

${ }^{40}$ Про практику розгляду судами клопотань про визнання й виконання рішень іноземних судів та арбітражів і про скасування рішень, постановлених у порядку міжнародного комерційного арбітражу на території України : Резолюція від 24.12.1999 p. № 12. URL: https://zakon.rada.gov.ua/laws/show/v001270099\#Техт. (дата звернення: 27.10.2020).
} 
«Дозволено все, що прямо не заборонено законом». А державні органи та їх посадові особи - за принципом «лише на підставі, в межах повноважень та у спосіб, що передбачувані Конституцією та законами України» (ч. 2 ст. 19 Конституції України). Інакше кажучи, їм дозволено лише те, що прямо визначено законом. А тепер виникає питання: чи $є$ МКАС при ТПП України державним органом?

На підставі ст. 2 Закону Україну «Про міжнародний комерційний арбітраж» ${ }^{41}$ ми можемо зробити висновок, що поняття «міжнародний комерційний арбітраж» $\mathrm{i}$ «третейський суд» $є$ тотожними номенклатурами. Своєю чергою ст. 2 Закону України «Про третейські суди» чітко встановлює, що третейські суди - це недержавні незалежні органи ${ }^{42}$.

Отже, на наше переконання, Міжнародний комерційний арбітражний суд, будучи третейським недержавним незалежним органом, не має дотримуватися припису «дозволено лише те, що прямо визначено законом». I тому ми можемо зробити висновок, що арбітражні судді (в українській юрисдикції), вибираючи певний підхід для визначення закону до арбітражної угоди, не мають і не змушені використовувати норми Конвенції 1958 р. Адже, навіть якщо остання $\epsilon$ частиною національного права України i має перевагу над іншими українськими актами законодавства, то вона (Конвенція 1958 р.) не $\epsilon$ вищою в ієрархії джерел права від ч. 2 ст. 19 Конституції України.

По-шосте, вибираючи закони України до арбітражного застереження, існує великий ризик скасування арбітражного рішення українськими національними судами. Наприклад, сторони не вибрали закон арбітражної угоди і звернулися у МКАС при ТПП України для вирішення спору. Арбітражна угода сторін укладена шляхом листування електронною поштою і паперового підписаного обома сторонами варіанту не має. Арбітр обирає право України, як право, що застосовується до арбітражної угоди i виносить рішення про факт існування арбітражного застереження та про свою компетенцію. Сторона, яка програла арбітраж, звертається в апеляційний суд для скасування арбітражного рішення, посилаючись на п. 1 (a) ст. 5 Конвенції 1958 р., мотивуючи це тим, що арбітражна угода $\epsilon$ нікчемною з огляду ч. 2 ст. 547 ЦК України, адже вчинена з недодержанням письмової форми. I як свідчить досліджена нами українська практика, такі арбітражні рішення були скасовані ${ }^{43}$. Звичайно, такі анулювання $€$

\footnotetext{
41 Про міжнародний комерційний арбітраж : Закон України від 24.02.1994 р. № 4002-XII. Дата оновлення: 15.12.2017. URL: https://zakon.rada.gov.ua/laws/show/4002-12\#Text. (дата звернення: 27.10.2020).

${ }^{42}$ Про Третейські Суди : Закон України від 11.05.2004 p. № № 1701-IV. Дата оновлення: 05.10.2016. URL: https://zakon.rada.gov.ua/laws/show/1701-15\#Text. (дата звернення: 27.10.2020).

${ }^{43}$ Kabrera Yu. The latest trends of annulment of the commercial arbitration awards in Ukraine: grounds, approaches, consequences. The Issues of Improving Legal Knowledge in the XXI century: the Unity of Theory and Practice: collective monograph / V. Benkivsky, M. Burdonosova, O. Chepik-Trehubenko, O. Holovko, etc. Lviv Toruń: Liha Press, 2019. P. 85-108. DOI: https://doi.org/10.36059/978-966-397-164-3/85-108.
} 
надзвичайно спірними з точки зору юридичної логіки, проте така ситуація в Україні існує і це факт.

Тому, вибираючи закони України до арбітражного застереження, українські національні суди потім скасовують арбітражні рішення на підставі того ж самого українського законодавства, незважаючи на компетенцію арбітражного суду, яку він (арбітражний трибунал) встановлює сам. I звідси випливає ще одна проблема - це, на нашу думку, застарілість положення у п. 1 (а) ст. 5 Конвенції 1958 р., що арбітражне застереження є недійсним за законом, якому сторони його підпорядкували. По-перше, через те, що продемонстрована нами вище світова арбітражна практика відкидає саму ідею того, що сторони могли підпорядкувати арбітражну угоду закону країни, який би підривав чинність арбітражного застереження. I, по-друге, положення Конвенції були розроблені у 1958 p. А вже у 1967 р. З'являється доктрина «Роздільності» separability/ severability, що вперше була сформульована Верховним судом США у справі Prima Paint Corporation v Flood \& Conklin Manufacturing Co., в якій суд постановив, що арбітражні застереження як правові норми $\epsilon$ відокремленими від договорів, в які вони включені (записані) ${ }^{44}$. I 3 цього моменту це означає, що і судді, і сторони можуть вибрати будь-яку систему права, яка може підтримати чинність арбітражної угоди і тому, необхідність такого положення про скасування арбітражного рішення за законом, якому сторону підпорядкували угоду про арбітраж взагалі відпадає. На нашу думку, він є рудиментарним, і рівень маніпуляції з ним у процесі скасування арбітражних рішень явно перевищує саму ідею доцільності його існування.

Отже, ми можемо просто підсумувати факти:

1) Конвенція 1958 р. є частиною національного законодавства України і має перевагу над нормами українського законодавства, але не превалює над Конституцією України;

2) Конвенція 1958 р. присвячена питанню визнання і виконання арбітражних рішень, а не проблемі визначення застосовуваного права до арбітражного застереження і прямих вказівок на це вона не містить (як і не містить закон України «Про МКА» чи Типовий закон ЮНСІТРАЛ) так само, як вона не має чітких посилань на критерії визначення місця винесення арбітражного рішення, хоча арбітри можуть застосовувати її положення для вибору закону до арбітражної угоди;

3) навіть посилаючись на Конвенцію 1958 р. арбітри мають вибір: або застосовувати матеріальне право договору, вибраного сторонами, або вибирати процесуальне право арбітражу як закон арбітражної угоди;

\footnotetext{
${ }^{44}$ Arbitration Award. URL: https://www.lawpipe.com/U.S.-Supreme-Court/Prima_Paint_Corp_v_Flood_Conklin_ Mfg.html. (дата звернення: 27.10.2020).
} 
4) відповідно до українського права, міжнародний комерційний арбітражний суд $\epsilon$ недержавним органом, а тому норма «дозволено лише те, що прямо визначено законом» на нього не розповсюджується і це означає, що арбітри в українській юрисдикції не мають обмежувати себе використанням українського законодавства (та Конвенцією 1958 р. як його частини), вибираючи підхід для визначення закону арбітражної угоди;

5) у Конвенції 1958 р. йдеться про визнання чинності арбітражних угод, а не про вибір закону місця винесення арбітражного рішення, навіть якщо арбітражне рішення потім буде скасоване завдяки такому вибраному закону (як це відбувається в українській практиці);

6) застосування закону України як права арбітражного застереження може призвести до скасування арбітражного рішення;

7) закони України не містять жодної прямої норми для вибору права до арбітражного застереження;

8) делокалізація арбітражу вже відбулася і місце проведення арбітражного засідання - це лише географічний показник, і тому закони lex fori, lex arbitri не несуть у собі зобов'язального елементу в процесі вибору підходу для визначення закону арбітражного застереження (до слова, така сама ситуація, коли мова йде про обрання матеріального права до суті спору). Навпаки, у світовій арбітражній практиці ми спостерігаємо тенденцію до зменшення будь-якого впливу законів місця проведення арбітражу, як на вибір матеріального права до суті спору, так само як і до вибору підходу для визначення закону до арбітражної угоди.

\section{ВИСНОВКИ}

Світова арбітражна практика розробила п'ять різних підходів до вибору закону, що регулює арбітражне застереження:

1) традиційний, що покладається на колізійні норми. Арбітражні судді можуть вибирати закон країни місця винесення арбітражного рішення до арбітражної угоди на підставі Конвенції 1958 р. або ж принципу «найбільш тісного зв'язку»;

2) Validation principle, або принцип надання юридичної сили;

3) закон основного договору регулює арбітражне застереження;

4) прямий метод;

5) презумпція арбітражного застереження

Арбітр міжнародного комерційного арбітражного суду має змогу застосовувати будь-який із вище перелічених підходів, проте основна мета і суть будь-якого 3 них - це підтримання чинності арбітражного застереження, тому, роблячи вибір на користь одного чи іншого підходу, арбітражний суддя керується мотивом. Якщо один метод веде до нікчемності арбітражного 
застереження, то арбітр буде застосовувати інший, той, який підтримає існування арбітражної угоди.

Арбітражний трибунал також аналізує, яким чином таке вибране до арбітражної угоди право може вплинути в подальшому на скасування арбітражного рішення, адже обов'язок судді міжнародного комерційного арбітражного суду - зробити все можливе, щоб винесене рішення не було скасоване.

Звертаючи особливу увагу на українську юрисдикцію, ми дійшли висновку, що в Україні існує тенденція уподібнення міжнародного комерційного арбітражу до національного правосуддя на підставі використання норм українського законодавства. Така ситуація відбувається як у сфері скасування арбітражних рішень, так і при виборі підходу для визначення права, що застосовується до арбітражної угоди. Застосування закону України до арбітражної угоди несе в собі ризик скасування арбітражного рішення. Тому ми не рекомендуємо вибирати українську систему права до арбітражних угод через негативні наслідки, до яких вона може призвести. Проте маємо надію, що ситуація зміниться найближчим часом.

Також, на наше переконання, досліджені нами факти вказують, що арбітри у МКАС при ТПП України не зобов'язані вибирати тільки законодавство України до арбітражних застережень і особливо лише на підставі Конвенції 1958 р., а навпаки, такий вибір є диспозиційним. Арбітр МКАС при ТПП України може застосовувати будь-який із вищевказаних підходів вибору закону до арбітражної угоди, розроблених світовою арбітражною практикою, через те, що: 1) жодного методу не вказано в українському законодавстві; 2) міжнародний комерційний арбітражний трибунал є недержавним органом i не має взагалі дотримуватися чітких приписів українського законодавства; 3) навіть коли мова йде про Конвенцію 1958 р., то вона надає арбітражному суду змогу вибирати право: або обирати матеріальне право контракту до арбітражного застереження, або закон країни винесення арбітражного рішення. Якщо обидва закони будуть призводити до підривання чинності арбітражного застереження, то арбітражний суд має використати будь-який інший метод для вибору закону до арбітражної угоди, щоб підтримати чинність арбітражного застереження; 5) головна мета арбітражного трибуналу - це не тільки винесення арбітражного рішення. Це винесення рішення, котре потім не буде скасованим. Тому і сама ідея підтримання чинності арбітражного застереження, і підхід вибору закону арбітражного застереження $є$ надзвичайно важливими моментами у всьому арбітражному процесі.

Через це, на наш погляд, українській юрисдикції варто звернути увагу на використання підходу презумпції дійсності арбітражного застереження, який вже зарекомендував себе як найбільш ефективний та результативний. 
Його використання суттєво заощадить час та кошти для сторін та унеможливить скасування арбітражного рішення, посилаючись на п. 1 (а) ст. 5 Конвенції 1958 р. в Україні. Впровадження такого прогресивного методу в українську систему може суттево підвищити конкурентоспроможність i авторитет МКАС при ТПП України та пришвидшить його подальший еволюційний процес.

\section{АНОТАЦІЯ}

Сторони контракту, як правило, вибирають матеріальне право до суті свого спору, проте зовсім рідко вказують закон арбітражного застереження. У такому випадку пошук застосовуваного права до арбітражної угоди здійснюється арбітром, який має враховувати чимало нюансів і, головне, підтримати чинність арбітражного застереження.

У статті досліджено та виокремлено підходи, за допомогою яких арбітри могли б вибирати систему права до арбітражного застереження, розроблені світовою практикою міжнародного комерційного арбітражу. А також детально проаналізовано ситуацію щодо вибору застосовуваного права до арбітражної угоди в українській юрисдикції. Одні методи вже є застарілими і демонструють свою неефективність, тому розвинулися нові, які випливають із міжнародного порядку і сприяють зменшенню скасувань арбітражних рішень.

Порівняння міжнародного досвіду з правовою реальністю України дає нам змогу віднайти і виправити прогалини в українському законодавстві, а також зрозуміти, в якому напрямі має рухатися МКАС при ТПП України, щоб стати максимально успішним та конкурентоспроможним на світовій арені.

\section{ЛITЕРАТУРA}

1. United Nations conference on Trade and Development Dispute Settlement. URL: https://unctad.org/en/Docs/edmmisc232add39_en.pdf. (дата звернення: 27.10.2020).

2. Bonomi A., Volken P. Yearbook of Private International Law / ed. A. Bonomi, P. Volken. Lausanne: Swiss Institute Comparative Law, 2009. 743 p.

3. Lew J.D.M., Mistelis L.A., Kröll S.M., Kröll S. Comparative International Commercial Arbitration. Alphen aan den Rijn : Kluwer Law International B.V., 2003. 992 p.

4. Redfern A., Hunter M. On International Arbitration. Oxford : Oxford University Press, 2015. 808 p.

5. Типовой закон ЮНСИТРАЛ о международном торговом арбитраже. URL: https://zakon.rada.gov.ua/laws/show/995_879. (дата звернення: 27.10.2020).

6. UNCITRAL Secretariat Guide on the Convention on the Recognition and Enforcement of Foreign Arbitral Awards (New York, 1958). URL: 
https://www.uncitral.org/pdf/english/texts/arbitration/NY-conv/2016_Guide_on_ the_Convention.pdf. (дата звернення: 27.10.2020).

7. Arbitration Award. URL: http://www.uniset.ca/lloydata/css/19921AC562.html. (дата звернення: 27.10.2020).

8. Rules of COIA. URL: http://coia.org/wp-content/uploads/2015/10/151001COIA-Arbitration-Rules.pdf. (дата звернення: 27.10.2020).

9. Arbitration Award. URL: http://newyorkconvention1958.org/index.php?lvl= notice_display\&id=886\&opac_view=6. (дата звернення: 27.10.2020).

10. Arbitration Award. URL: http://www.bailii.org/cgi-bin/format.cgi?doc=/ew/ cases/EWCA/Civ/2012/638.html\&query=(A3/2012/0249); https://www.trans-lex. org/311350/_sulamerica-cia-nacional-de-seguros-sa-v-enesa-engenharia-sa-\%5B20 12\%5D-ewca-civ-638/. (дата звернення: 27.10.2020).

11. Berger K.P. Re-Examining the Arbitration Agreement, Applicable Law Consensus or Confusion? URL: https://www.trans-lex.org/100680/_/bergerklaus-peter:-re-examining-the-arbitration-agreement-applicable-law-consensus-orconfusion-in:-van-den-berg-icca-congress-ser-no13-international-arbitration-2006:back-to-basics-/\#Footnote-817476356603a56a2029b62796fe7833 (дата звернення: 27.10.2020).

12. Arbitration Award. URL: https://www.supremecourt.uk/cases/docs/uksc2020-0091-judgment.pdf, Р. 59-60. (дата звернення: 27.10.2020).

13. Swiss Private International Law Act (Chapter 12: international arbitration) : A Comentary. URL: https://www.swlegal.ch/media/filer_public/9d/b2/9db2005218a2-4b68-a131-e70ff5bb7ec3/150921_anya-george_swiss-private-internationallaw-act-chapter-12-international-arbitration.pdf. (дата звернення: 27.10.2020).

14. Act $60 / 2003$ on Arbitration. URL: https://www.mjusticia.gob.es/cs/Satellite/ Portal/1292426982249?blobheader=application\%2Fpdf\&blobheadername1= Content-Disposition\&blobheadervalue $1=$ attachment $\% 3 B+$ filename\%3DAct_on arbitration_\%28Ley_60_2003_de_arbitraje\%29.PDF (дата звернення: 27.10.2020).

15. Session of Santiago de Compostela - 1989 Arbitration Between States, State Enterprises, or State Entities, and Foreign Enterprises. URL: https://www.idi-iil.org/app/uploads/2017/06/1989_comp_01_en.pdf （дата звернення: 27.10.2020).

16. Alvik I. Contracting with Sovereignty: State Contracts and International Arbitration. London : Bloomsbury Publishing, 2011. 346 p.

17. Graffi L. The law applicable to the validity of an arbitration agreement: a practitioner's view. URL: https://books.google.co.il/books?id=Zx4eFIqD0wsC\& $\mathrm{pg}=\mathrm{PA} 51 \& \mathrm{lpg}=\mathrm{PA} 51 \& \mathrm{dq}=\mathrm{lew}+$ there + is $+\mathrm{a}+\mathrm{very}+$ strong + presumption $+\mathrm{in}+$ favour +of+the+law+governing+the+substantive+agreement+which+contains+the+arbitr ation+clause+also+governing+the+arbitration+agreement\&source=bl\&ots=E9RR p9YB4q\&sig=ACfU3U3FB5sku4OFrSj2vi2OrEECGIB8Pw\&hl=ru\&sa=X\&ved= 
2ahUKEwje9dvd0tPoAhXLDOwKHY8vA3oQ6AEwAXoECAsQNQ\#v=onepag e\&q=lew\%20there \%20is\%20a\%20very\%20strong\%20presumption\%20in\%20fav our $\% 20$ of $\% 20$ the $\% 20$ law $\% 20$ governing $\% 20$ the $\% 20$ substantive $\% 20$ agreement $\%$ 20which $\% 20$ contains $\% 20$ the $\% 20$ arbitration $\% 20$ clause $\% 20$ also $\% 20$ governing $\%$ 20the\%20arbitration\%20agreement\&f=false. (дата звернення: 27.10.2020).

18. Arbitration Award. URL: http://www.bailii.org/ew/cases/EWHC/Comm/ 2001/481.html, 32. (дата звернення: 27.10.2020).

19. Arbitration Award. URL: https://www.supremecourt.gov.sg/docs/defaultsource/module-document/judgement/bcy-v-bcz-(for-release)-(08-11-2016)-pdf. pdf, 32. (дата звернення: 27.10.2020).

20. Arbitration Award. URL: https://indiankanoon.org/doc/216597/. (дата звернення: 27.10.2020).

21. Arbitration Award. URL: https://www.casemine.com/judgement/uk/ 5a8ff73160d03e7f57ea96dd. (дата звернення: 27.10.2020).

22. Rubino-Sammartano M. International Arbitration Law and Practice. Huntington NY : Juris Publishing, 2014. 2072 p.

23. Arbitration Award. URL: https://www.legifrance.gouv.fr/affichJuriJudi. do? oldAction $=$ rechJuriJudi\&idTexte=JURITEXT000007030314\&fastReqId $=126$ 0648628\&fastPos=1. (дата звернення: 27.10.2020). Див також англ. переклад https://books.google.co.il/books?id=pcvfDgAAQBAJ\&pg=PT205\&lpg=PT205\& $\mathrm{dq}=$ Municipalite $+\mathrm{de}+$ Khoms + El + Mergeb $+\mathrm{v} .+$ Societe + Dalico\&source $=\mathrm{bl} \&$ ots $=$ KSIM6YvT_f\&sig=ACfU3U2jc_1J0AvUKA8XzOAPpCBYBhbSBg\&hl=ru\&sa $=X \& v e d=2$ ahUKEwjGotyBpaboAhUTnVwKHbf8D1cQ6AEwBXoECAgQAQ\#v $=$ onepage $\& q=$ Municipalite $\% 20 \mathrm{de} \% 20 \mathrm{Khoms} \% 20 \mathrm{El} \% 20 \mathrm{Mergeb} \% 20 \mathrm{v} . \% 20$ Societ e\%20Dalico\&f=false. (дата звернення: 27.10.2020).

24. Webster T.H., Dr Buhler M. Handbook of ICC Arbitration: Commentary, Precedents, Materials. London : Sweet \& Maxwell, 2014. 874 p.

25. Arbitration Award. URL: https://www.legifrance.gouv.fr/affichJuriJudi.do? oldAction=rechJuriJudi\&idTexte=JURITEXT000020837816\&fastReqId=1282389 989\&fastPos=1. (дата звернення: 27.10.2020).

26. Alvik I. Contracting with Sovereignty: State Contracts and International Arbitration, Bloomsbury Publishing, 2011.366 p.

27. Arbitration Award. URL: https://www.legifrance.gouv.fr/affichJuriJudi.do? idTexte=JURITEXT000007031033. (дата звернення: 27.10.2020).

28. Arbitration Award. URL: https://www.legifrance.gouv.fr/affichJuriJudi.do? idTexte=JURITEXT000007099879. (дата звернення: 27.10.2020).

29. Arbitration Award. URL: https://www.legifrance.gouv.fr/affichJuriJudi.do? idTexte=JURITEXT000032600615. (дата звернення: 27.10.2020).

30. Liebscher C., Alice A. Fremuth-Wolf . Arbitration Law and Practice in Central and Eastern Europe. Huntington : Juris Publishing, Inc., 2006. 1132 p. 
31. Про міжнародні договори України : Закон України від 29.06.2004 р. № 1906-IV. Дата оновлення: 02.01.2020. URL: https://zakon.rada.gov.ua/laws/ show/1906-15\#Text. (дата звернення: 27.10.2020).

32. Конституція України: офіційний текст. URL: https://zakon.rada.gov.ua/ laws/show/254\%D0\%BA/96-\%D0\%B2\%D1\%80\#Text. (дата звернення: 27.10.2020).

33. Окрема думка судді Конституційного суду України Тупицького О.М. від 21.03.2014 P. URL: https://zakon.rada.gov.ua/laws/show/nb02d710-14\#Text. (дата звернення: 27.10.2020).

34. Про застосування Конституції України при здійсненні правосуддя : Постанова Пленуму Верховного Суду від 01.11.1996 p. № 9. URL: https://zakon.rada.gov.ua/laws/show/v0009700-96\#Text. (дата звернення: 27.10.2020).

35. Декларація про державний суверенітет України від 16.07.1990 p. № 55-XII. URL: https://zakon.rada.gov.ua/laws/show/55-12\#Text. (дата звернення: 27.10.2020).

36. Gary B. Born International Arbitration: Law and Practice, The Netherlands : Walters Kluwer, 2012. 480 p.

37. Ватрас В.А. Загальновизнані принципи і норми міжнародного права як джерела публічного та приватного права. URL: http://www.univer.km.ua/ statti/20.vatras_v.a._zahalnovyznani_pryntsypy_i_normy_mizhnarodnoho_prava_ yak_dzherel_publichnoho_ta_pryvatnoho_prava.pdf. (дата звернення: 27.10.2020).

38. UNCITRAL: Secretariat Guide on the Convention on the Recognition and Enforcement of Foreign Arbitral Awards. URL: https://www.uncitral.org/ pdf/english/texts/arbitration/NY-conv/2016_Guide_on_the_Convention.pdf. (дата звернення: 27.10.2020).

39. Про практику розгляду судами клопотань про визнання й виконання рішень іноземних судів та арбітражів і про скасування рішень, постановлених у порядку міжнародного комерційного арбітражу на території України : Резолюція від 24.12.1999 p. № 12. URL: https://zakon.rada.gov.ua/laws/ show/v0012700-99\#Text. (дата звернення: 27.10.2020).

40. Про міжнародний комерційний арбітраж : Закон України від 24.02.1994 p. № 4002-XII. Дата оновлення: 15.12.2017. URL: https://zakon.rada.gov.ua/laws/show/4002-12\#Tеxt. (дата звернення: 27.10.2020).

41. Про Третейські Суди : Закон України від 11.05.2004 р. № № 1701-IV. Дата оновлення: 05.10.2016. URL: https://zakon.rada.gov.ua/laws/show/ 1701-15\#Tехt. (дата звернення: 27.10.2020).

42. Kabrera Yu. The latest trends of annulment of the commercial arbitration awards in Ukraine: grounds, approaches, consequences. The Issues of Improving Legal Knowledge in the xxi century: the Unity of Theory and Practice: collective 
monograph / V. Benkivsky, M. Burdonosova, O. Chepik-Trehubenko, O. Holovko, etc. Lviv - Toruń : Liha Press, 2019. P. 85-108. DOI: https://doi.org/10.36059/978-966-397-164-3/85-108.

43. Arbitration Award. URL: https://www.lawpipe.com/U.S.-Supreme-Court/ Prima_Paint_Corp_v_Flood_Conklin_Mfg.html. (дата звернення: 27.10.2020).

Information about author:

Kabrera Yu. F.,

Postgraduate Student

International Humanitarian University 33, Fontanska doroha str., Odesa, 65000, Ukraine 